\title{
Idle Youth and Macroeconomics in Latin America
}

\author{
Luis Rene Caceres ${ }^{1}$ \\ ${ }^{1}$ Independent Researcher, El Salvador \\ Correspondence: Luis Rene Cáceres, 5456 Paseo General Escalón, San Salvador, El Salvador.
}

Received: July 24, 2021

Accepted: December 28, $2021 \quad$ Online Published: December 30, 2021

doi:10.5539/ijef.v14n1p98

URL: https://doi.org/10.5539/ijef.v14n1p98

\begin{abstract}
This paper analyzes the macroeconomic repercussions of the existence of idle youth in a cross-section of Latin American countries. The results indicate that idle youth has a close association with the indices of gender inequality and governance, and with informality. By estimating a series of equations, it was possible to infer that idle youth exerts adverse effects on economic growth, the domestic saving rate and economic vulnerability. It is also reported that the prevention of idle youth rests on substantial increases in tax revenues so as to increase social spending.
\end{abstract}

Keywords: unemployment, fertility, economic integration, economic instability

JEL: E26, H52, J13, J16

\section{Introduction}

The study of the segment of the young population of a country that neither studies or works, called NEETs, has received considerable attention in recent years. This interest lies in the evidence that the situation of NEET can lead to parents transmitting their poverty to their daughters or sons from one generation to another. As well, the role of male NEETs in generating violence has been pointed out by several authors (Caceres, 2021). As it represents an obstacle to increasing labor force participation, the NEET population can lead to a reduction in the rate of economic growth.

This paper analyzes the repercussions arising from the female and male NEET populations, using data from a sample of 14 Latin American countries, taken from de Hoyos, Rogers and Popova (2016). The first section presents a brief review of the selected literature; this is followed by a discussion of stylized facts about NEETs in the region. Next, the data and the results of the estimation of equations are presented, which allow one to appreciate the associations between the percentages of female NEETs and indicators of gender inequality, governance, and informality, among others. The following section presents an analysis of the relationship between the percentage of female NEETs, economic growth, and taxation, showing that low taxation is a determinant of the young population entering the situation of NEET. Given that the situation of NEETs is not conducive to increasing household income, NEETs can have negative impacts on savings, and therefore on investment, growth, and economic stability. The work ends with a series of conclusions.

\section{Review of the Literature}

Below is a brief review of relevant literature about idle youth in Latin America.

de Hoyos, Rogers, and Popova (2016) presented a diagnosis of the percentages of NEETs in 15 Latin American countries using data of the period 1990-2010. They reported that, in 2010, of the total population of the region between 15 and 24 years old, 34 percent only studied, 33 only worked, 12 percent studied and worked, and 19 percent, or a total of 18.2 million, was in the category of NEET.

They also reported that in the period 1990-2010 the percentage of the NEET population fell from 23.4 to 19.3 percent, although in absolute terms it increased from 16.4 to 18.2 million. The number of male NEETs increased 46 percent, which explains the increase in the total number of NEETs in the period. In 2010, R. B. Venezuela and Peru had the lowest percentages of NEETs in the region (10.9 and 13.0 percent), while the Central American countries (except Costa Rica) had the highest percentages.

The authors also indicated that in 2010 the existence of NEETs was more marked in rural areas, at 21 percent, higher than the percentage of 16.8 percent in urban areas, but the opposite occurred in terms of population: 13 of the 18 million NEETs were in urban areas. 
There are disparities in the incidence of the situation of NEETs by the distribution of national income: in 2010, of the young population of the first decile, 30.5 percent were in the state of NEETs, but only 6.6 percent of the top decile was in that situation.

Regarding the level of education, in 2010 the NEET population that had not reached the primary level was 15 percent, and 20 percent had not finished the secondary level. The authors point out that in the population aged 15-18 years, the main reason for being in a NEET situation was having dropped out of school, while the NEET stratum aged 18 to 24 had a high percentage of completed secondary education; therefore, the situation of NEET in this group could be explained by the low quality of education.

Regarding the structure by sex, 68.6 percent of NEETs were female in 2010, of which 35.5 percent lived with their parents and were not looking for work, and 17.6 percent had started a household and had children. Men occupied 31.4 percent of the NEET population; of these, 29.7 percent lived with their parents, and 15 percent were not looking for work.

The highest percentage of NEETs in 2010 were between 19 and 24 years old, 68 percent of the total. This percentage increased between 1990 and 2010 by 1.7 million, while the 15-18 age group remained constant.

It should be noted that a higher percentage of female NEETs do not seek work in relation to male NEETs: 87.4 and 69.7 percents of the 15 to 18 -year-old group, and 80.2 and 44.4 of women and men, respectively, between 19 and 24 years. In other words, there is a greater "resignation" in the group of female NEETs, probably related to situations of being pregnant, or caring for children or adults in the home.

Cardenas, de Hoyos and Szekely (2006) analyzed the variables associated with the probability that young people of both sexes belonged to the NEET category, in a sample of 18 Latin American countries, with panel data from household surveys from 1989 to 2010. The estimation of probit models for the sample of young people between 15 and 18 years old, showed that the variables that reduced the probability of being in the NEET situation were the increases in per capita household income, and the education level and age of the head of the household; this probability decreased when the head of the household was employed, and increased if the head of the household was a woman, and with the size of the household. The most determining variable for being a NEET was the per capita income of the household, that is, poverty, followed by the event that the head of the household was employed, and the level of education of the latter.

The analysis of the cohorts of different ages led the authors to conclude that the situation of NEET was mainly due to the fact that they had dropped out of school.

These authors also estimated equations with panel data for the period 1980-2010 for 18 Latin American countries, expressing the percentages of NEETs in each country in terms of macroeconomic and social variables. The results indicated that in the case of male NEETs, economic growth had a negative impact on the 15-18 age groups; however, in the case of female NEETs this variable was not significant. In other words, the variables that lead young women to enter the NEET situation were not related to economic dynamism. The implication is that, given that the percentages of female NEET have fallen in all the countries of the region in the period 1990-2010, this reduction should not be attributed to economic growth, but to other variables, such as the increase in female labor force participation and the expansion of education.

In the case of young males, per capita income was not related to being NEET, but for female NEETs, GDP per capita had a negative impact, that is, at higher levels of economic development, the percentage of female NEET tended to fall.

The opening of the economy had a positive impact on increasing the male NEETs of both age groups, but it was not significant in the case of female NEETs.

The national unemployment rate did not show any negative impact on male NEETs between 15 and 18 years old, but it was significant and positive in the male group between 18 and 24 years old. The same is noted in the group of female NEETs of both age groups.

Years of schooling had no impact on male NEETs of both age groups, but had a negative impact on both age groups of female NEETs. In other words, education "protects" young women from becoming NEETs.

In both age groups, the fertility rate increased the percentage of female NEETs.

\section{The Data}

The data for female and male NEET is taken from de Hoyos, Rogers, and Szekely (2016), while data of an economic and social nature were obtained from the World Bank's World Development Indicators. All data correspond to 2010 . 


\section{Results}

\subsection{Relationship between Percentages of Female and Male NEETS}

This paper emphasizes the behavior of the percentage of female NEETs, (ninifeme2010), in responses to changes in other variables, since the percentage of female NEETs has an inverse relationship with the percentage of male NEETs, (ninimasc2010).

The fact is that the percentages of female NEETs have a negative relationship with the GDP per capita, (PIBPC2010), of the respective countries (Figure 1); on the contrary, the percentages of male NEETs show a positive relationship (Figure 2).

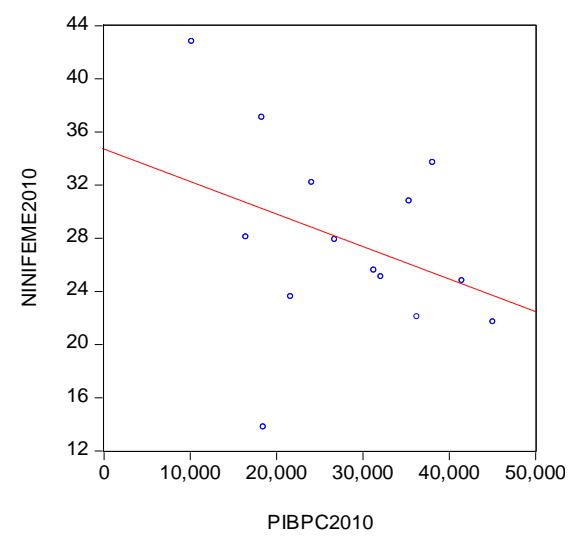

Figure 1. GDP per capita and percentages of female NEETs

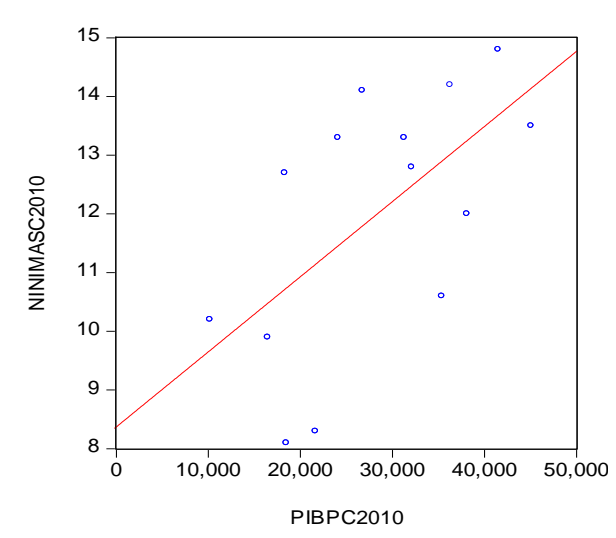

Figure 2. GDP per capita and percentages of male NEETs

In other words, as per capita GDP in Latin American countries increases, the percentage of female NEETs decreases, while that of male NEETs increases.

This gives rise to a negative relationship between female and male NEETs, as shown in Figure 3, where the "outliers" below the regression line are Peru and Ecuador. An estimated equation for the percentage of male NEETs in terms of the percentage of females, and of the qualitative variables corresponding to the countries indicated above, explains 68 percent of the variance of the percentage of male NEETs:

Male NEET $=17.8238-0.1801$ Female NEET -7.5018 CualiPeru - 5.3838 CualiEcuador

(10.14) (3.11)

R squared $=0.68$

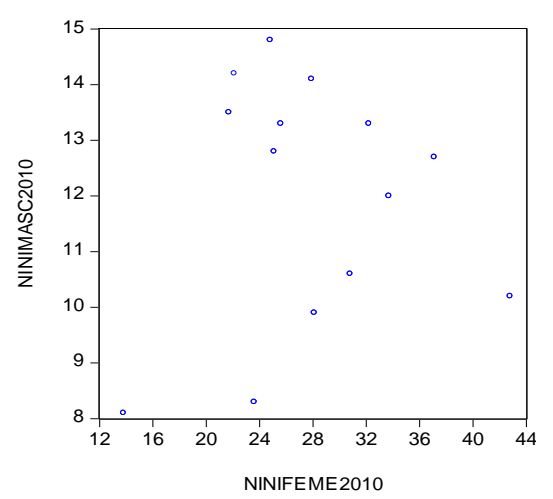

Figure 3. Percentages of female and male NEETs

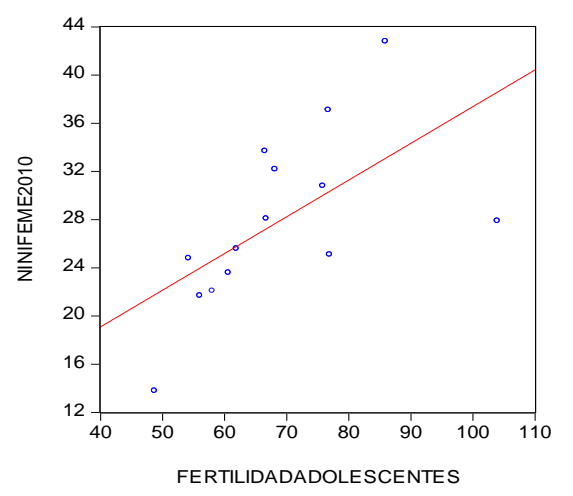

Figure 4. Adolescent fertility rate and percentage of female NEET

The relationship shown in Figure 3 can be explained by the existence of a positive association between the adolescent fertility rate, (fertilidadadolescentes), and the percentage of female NEET (Figure 4).

In Latin America, the fertility rate of adolescents falls as the per capita income of the respective countries increases, as can be seen in Figure 5. 


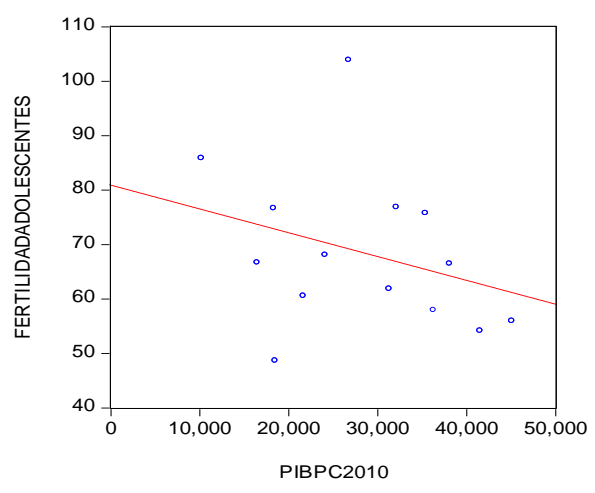

Figure 5. GDP per capita and adolescent fertility rate

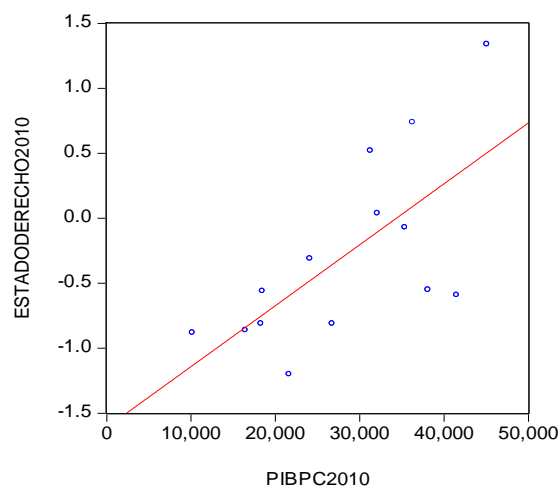

Figure 6. GDP per capita and Indicator of the rule of law

The explanation lies in the fact that countries with higher per capita GDP have better indicators of the rule of law, as can be seen in Figure 6, which implies greater respect for the law and, therefore, less tolerance for impunity in relation to abuse of adolescents and, consequently, their fertility rate falls as the rule of law indicator, (estadoderecho), increases (Figure 7). This explains the drop in the percentage of female NEET as per capita GDP increases.

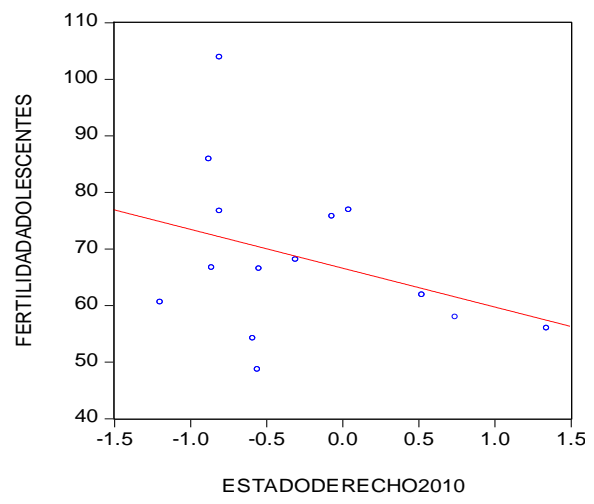

Figure 7. Indicator of rule of law and adolescent fertility rate

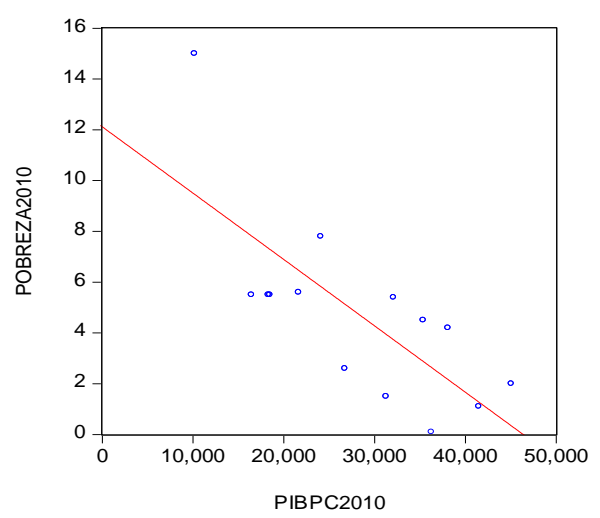

Figure 8. GDP per capita and poverty rate

On the other hand, the positive relationship between the percentage of male NEET and GDP per capita is explained by the fact that this last variable has a negative relationship with the poverty rate, (pobreza2010), as seen in Figure 8.

Faced with a high rate of poverty, young males are urged to work to support their homes and ensure their subsistence, and therefore do not choose to enter the situation of NEET.

Young women would also feel the urgency to work in the face of poverty (Figure 9), but due to their conditions as mothers, or as providers of household services, whether it be domestic work, or taking care of other members of the household, they must enter the bulk of the NEETs.

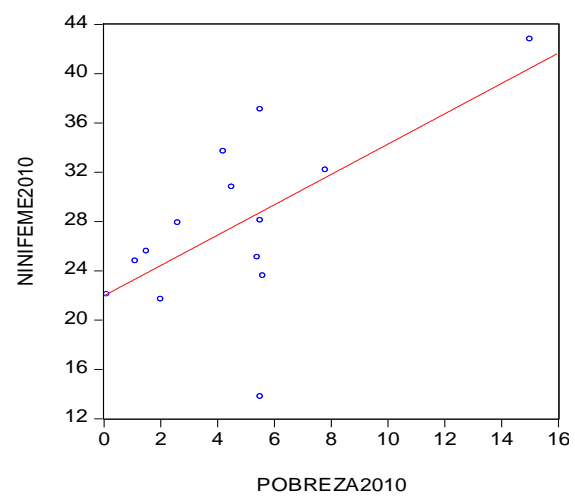

Figure 9. Poverty rate and percentage of female NEET 


\subsection{Determinants of the Percentages of Female Neets}

Next, the estimation of equations that express the percentage of female NEETs in terms of various economic and social variables is presented. Equation (1) of table 1 shows that the adolescent fertility rate has a positive and significant coefficient, and with the qualitative variable CualiDR, which represents the case of the Dominican Republic, explain 75 percent of the variance of the percentage of female NEETs.

It has been pointed out in the context of NEETs that adolescent fertility is associated with situations of poverty and lack of opportunities. In fact, Figure (10) shows the negative relationship between the human opportunity index, $\mathrm{IOH}$, which is an indicator of equality of opportunities (Note 1), and the adolescent fertility rate.

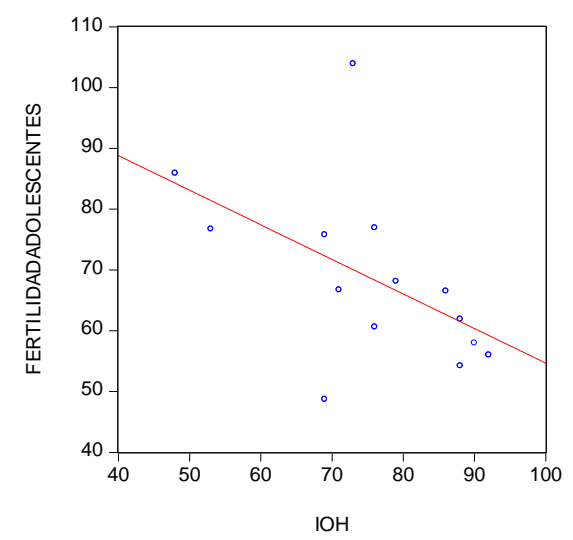

Figure 10. Human opportunity index, IOH, and adolescent fertility rate

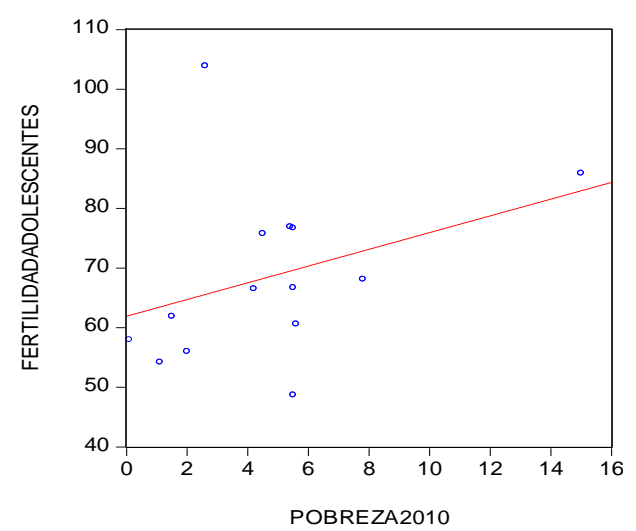

Figure 11. Poverty gap and adolescent fertility rate

Furthermore, adolescent fertility is closely associated with the poverty gap in the respective country, as can be seen in Figure 11.

Equation (2) corroborates what is shown in graph 10, since the IOH has a negative and significant coefficient, and, with the qualitative variable CualiPeru, explains 75 percent of the variance of the percentage of female NEET. This indicates that the female NEET experience reflects the absence of opportunities for social mobility.

In equation (3) the compound term Fertility * IOH is introduced, and it has a negative and significant coefficient, indicating that social mobility reduces the impact of adolescent fertility on girls becoming NEETs. In the case of Honduras, an increase in the IOH by 25 points, to reach 75, would contribute to reducing the role of adolescent fertility in the percentage of NEETs by about 50 points. It can be calculated that when the IOH reaches the value of 92.8, close to the value corresponding to Chile, the impact of adolescent fertility on the percentage of NEETs disappears,

In other words, the tragedy of the NEETs is mainly due to the lack of opportunities to access the services of health, education, electricity, housing, and potable water, which result from the fiscal weakness of the public sector, which is not able to attend the legitimate needs of a significant percentage of the young population, given the low tax revenues and high tax evasion prevailing in many Latin American countries.

This is corroborated by equation (4), which shows that public spending on education as a percentage of GDP, (Gastoeducacion), has a negative and significant coefficient, and the equation explains 38 percent of the variance. That is, two-fifths of the variability of the female NEET is explained by public spending on education. The increase in education spending would help young women avoid wasting their lives.

Equation (5) shows that the percentage of the population that has reached the secondary level, (Secondary), has a negative and significant coefficient, and the equation explains 57 percent of the variance, while equation (6) shows that the indicator of Control of Corruption, taken from the World Bank's Governance Indicators, has a negative and significant coefficient, which implies that as this indicator increases, impunity and arbitrariness in relation to the abuse of female adolescents is reduced.

In equation (7) it is observed that the gender inequality index, IDG, has a positive coefficient and the equation explains 55 percent of the variance of the percentage of female NEETs. An implication is that the determination of the percentage of female NEET is associated with gender discrimination and is also related to opportunities for social mobility and to the weaknesses of the rule of law. 
The composite variable IDG* $\mathrm{IOH}$ is introduced into equation (8) and it is observed that its coefficient is negative and significant, indicating that equality of opportunities reduces the incidence of gender inequality on female NEET. The role of the IOH is such that when it reaches a value of 85 it cancels out the impact of gender discrimination; it should be noted that only four countries in the region have IOH values above 85 .

Table 1. Dependent Variable: Percentage of female NEETs

\begin{tabular}{|c|c|c|c|c|c|c|c|c|c|c|c|}
\hline \multirow[b]{2}{*}{ Independent Variables: } & \multicolumn{11}{|c|}{ Equation number: } \\
\hline & (1) & (2) & (3) & (4) & (5) & (6) & (7) & (8) & (9) & (10) & (11) \\
\hline \multirow[t]{2}{*}{ Constant } & -14.4697 & 57.2667 & 23.5824 & 38.8178 & 41.8885 & 28.4957 & 1.4232 & 25.3478 & 9.8344 & 23.1826 & 18.4771 \\
\hline & $(2.10)$ & $(10.53)$ & $(3.67)$ & (7.39) & $(9.43)$ & $(24.56)$ & $(0.57)$ & $(2.89)$ & $(4.88)$ & (18.07) & $(9.02)$ \\
\hline \multirow[t]{2}{*}{ CualiRD } & -21.6013 & & -14.2982 & & -3.0783 & -5.0921 & -3.2362 & -16.4173 & 3-22.0991 & $1-10.7041-$ & -13.3575 \\
\hline & $(4.12)$ & & $(3.52)$ & & $(2.94)$ & (3.68) & $(3.04)$ & $(4.81)$ & $(4.88)$ & (3.34) & $(5.12)$ \\
\hline \multirow[t]{2}{*}{ Adolescent Fertility } & 0.6116 & & 0.4176 & & -0.2713 & & & & & 0.247 & \\
\hline & $(6.28)$ & & $(5.09)$ & & $(2.96)$ & & & & & $(6.36)$ & \\
\hline \multirow[t]{2}{*}{ CualiPeru } & & -17.4672 & & & & -4.7204 & & & 78.4995 & & \\
\hline & & $(5.11)$ & & & & $(3.21)$ & & & $(4.80)$ & & \\
\hline \multirow[t]{2}{*}{$\mathrm{IOH}$} & & -0.3737 & & & & & 64.6647 & 68.4152 & -0.709 & & \\
\hline & & $(5.24)$ & & & & & $(3.47)$ & $(4.77)$ & $(3.05)$ & & \\
\hline \multirow[t]{2}{*}{ Adolescent Fertility * $\mathrm{IOH}$} & & & -0.0045 & & & & & -0.8054 & & & 0.1705 \\
\hline & & & $(3.84)$ & & & & & $(3.50)$ & & & $(2.74)$ \\
\hline \multirow[t]{2}{*}{ Gasto Educacion } & & & & -2.5018 & 0.57 & 0.56 & 0.55 & 0.76 & 0.69 & 0.84 & 0.86 \\
\hline & & & & $(2.40)$ & $(5)$ & $(6)$ & $(7)$ & $(8)$ & $(9)$ & $(10)$ & (11) \\
\hline $\mathrm{R}^{\wedge} 2$ & 0.75 & 0.75 & 0.76 & 0.38 & 41.8885 & 28.4957 & 1.4232 & 25.3478 & 9.8344 & 23.1826 & 18.4771 \\
\hline
\end{tabular}

The variable trust in government, Trust, is included in equation (9) as the composite variable IDG*Trust, which has a negative and significant coefficient, indicating that trust in the government, which is associated with the perception that national authorities are committed to the fight against poverty (Cáceres, 2019), reduces the adverse impact of gender discrimination on female NEET.

Equation (10) shows that the coefficient for the homicide rate per 100,000 inhabitants, (homicidios), has a positive coefficient, and the equation explains 84 percent of the variance of the percentage of female NEETs. The homicide rate represents, as Cáceres (2017) has shown, situations in a given country of low social mobility, high corruption, informality, and low taxation that, as observed in this equation, have a decisive impact on female NEET. This shows that the problem of NEETs can be addressed through social policies that promote human capital, governance and social mobility.

It should be mentioned that de Hoyos, Rogers, Szekely (2016) reported for the case of the States of Mexico, the existence of a positive relationship between the homicide rate and the percentage of male NEETs in the respective state; they also pointed out that the determining variables of violence were the increase in the percentage of male NEETs, the lack of job opportunities, and the offer of employment to young people by criminal groups.

In equation (11) the variable Shadow is added, which measures the underground economy in a given country, and its coefficient is positive and significant. There is evidence that the underground economy in Latin American countries is a manifestation of the limited supply of social goods, which is the result of low social spending, (Cáceres, 2013), which gives rise to self-employment. This can be associated with the low taxation that prevails in the countries of the region.

The equations presented in Table 1 show that much of the NEET problem can be solved through the design and implementation of public policies conducive to increasing equal opportunities, particularly access to quality education; likewise, the quality of institutions plays an important role in preventing the phenomenon of NEETs. But these policies, the implementation of which could represent significant advances in providing youth with a life of personal fulfillment, and the counry in question with a trajectory of sustained development, meet the determining obstacle of low tax revenues. In Latin America, it seems that greed and myopia have had more weight than providing services to youth. 


\subsection{Female Neet and Economic Growth}

Graph 12 analyzes the different repercussions of the percentage of female NEET population on economic and social variables of a typical Latin American country, and also on variables of neighboring countries. It is assumed that the phenomenon of female NEET occurs in member countries of an economic integration scheme.

Quadrant (1) shows that when tax revenues increase, Tax, public spending on education, Gasto, also increases, under the assumption that there is a commitment by the authorities to allocate additional tax resources to this sector.

Quadrant (2) presents the positive relationship between spending on education and its quality, Calidad, which has been demonstrated by Cáceres (2018) for the Latin American countries.

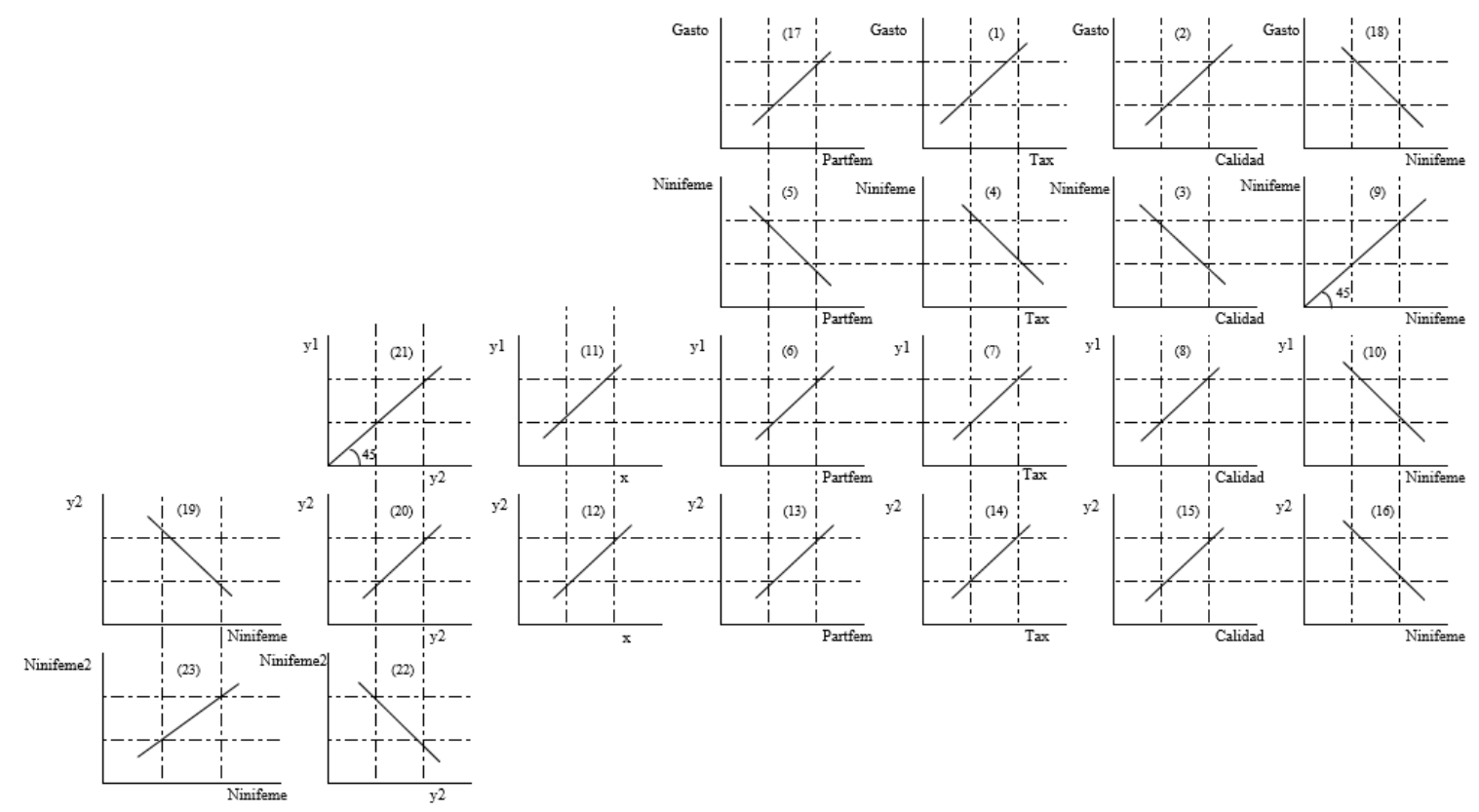

Figure 12. Implications of the percentages of female NEET on economic growth in an economic integration scheme

Quadrant (3) shows that the incidence of female NEET decreases as the quality of education, Calidad, increases, as shown in Figure 13. In this Figure the third grade reading score, (Tercerolectura), has been used as an indicator of education quality of the Latin American countries, taken from the Third Regional Test of Quality of Education, carried out in 2013 (Terce, 2016).

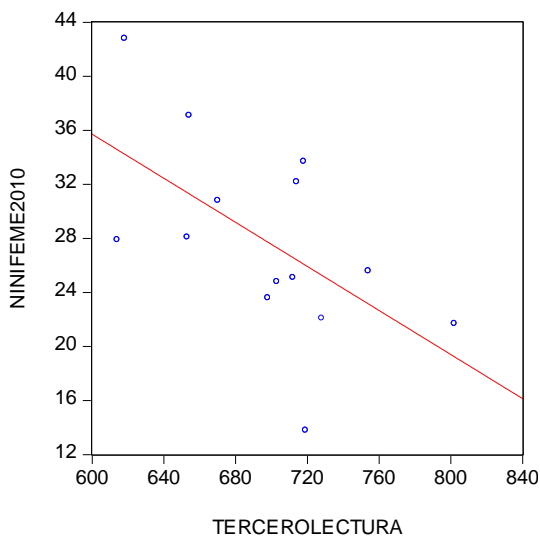

Figure 13. Third grade reading scores and percentages of female NEET



Figure 14. Per capita taxes paid in 1870 and percentage of female NEET in 2010 
With quadrants (1) and (3), the inverse relationship between tax revenues and the percentage of female NEETs in the respective country is constructed in quadrant (4). In this paper, tax collection is represented by the amount of per capita taxes paid in nine Latin American countries in 1870, taken from and Sokoloff and Zolt (2004). This indicator is closely associated with the percentage of female NEETs in 2010, and with other current economic and social variables, and shows that the fiscal weakness of the countries has been reproducing. The relationship between per capita tax revenues in 1870, Tax1870, and the percentage of female NEETs in 2010, is shown in Figure 14.

This indicates that increasing taxation with a view to improving the quality of education is a means to reduce the percentage of female NEET, highlighting the important role of fiscal policy, and particularly of tax revenues, in solving the problem of the NEETs in Latin America.

Quadrant (5) shows the negative relationship between the percentage of female NEETs in a given country and the respective female labor participation rate, Partfem. In quadrant (6) it is observed that the increase in the female labor participation rate leads to an increase in the economic growth rate, y1, which has been demonstrated by Ostry et al (2018) for a sample of countries, see Figure 15.



Figure 15. Female participation and economic growth rate



Figure 16. Per capita tax revenues paid in 1870 and average economic growth rate 2005-2012

Quadrant (7) shows the relationship between tax revenues and economic growth, which demonstrates the role of fiscal policy in promoting economic growth. This relationship is shown in Figure 16.

Quadrant (8) shows the positive relationship between the quality of education and economic growth, which has been evidenced for Latin American countries by Hanushek and Woessmann (2009) and by Cáceres (2018b). Using the 45-degree line shown in quadrant (9), quadrant (10) presents the negative association between the percentage of female NEETS and the rate of economic growth. This relationship is shown in Figure 17.



Figure 17. Percentage of female NEET and economic growth rate

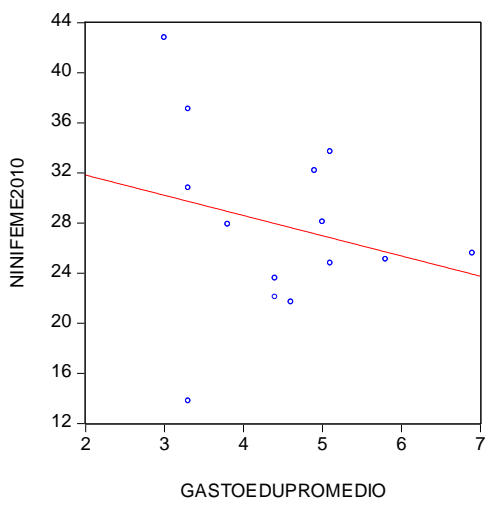

Figure 18. Expenditure on education and percentage of female NEET

Quadrant (11) shows that increased economic growth in country 1 leads to an increase in its imports, $x$, from country 2 . By increasing its exports, $x$, to country 1 , country 2 would experience an increase in its economic growth rate, y2 (quadrant 12). It is observed that the economic growth of country 2, y2, is positively associated with the female participation rate, tax revenues, and the quality of education in country 1 , as observed in the 
quadrants (13), (14), and (15). Of particular interest is the relationship in quadrant (16) which shows that the reduction in the percentage of female NEET in country 1 leads to increased growth in country 2.

In an economic integration scheme, the fall in the percentage of female NEETs in each country generates repercussions or "spillovers" of economic growth towards the other member countries, so that the integration scheme as a whole acquires dynamism. Thus, combating the problem of NEETs should be seen as an element of a regional social policy, given the potential impact on imparting dynamism to trade flows between countries, thus imparting resilience to the integration scheme.

An extensive literature has reported that the dynamism of economic integration schemes tends to "run out" after a period of operation, which has been erroneously linked to the "commercial discrimination" of the import substitution scheme, and to the "inefficiency" of trade diversion. If there is a decline in the progress of regional economic integration, it can be explained by the fact that the social spending of the member countries is so low that does not guarantee a minimum level of social development required to generate adequate levels of health and education, not only to satisfy the human rights of the population, but also to reach adequate income levels that result from increasing intra-regional trade.

Using quadrants (1) and (5), the positive relationship between spending on education and female participation is obtained in quadrant (17).

Likewise, based on quadrants (2) and (9), the negative relationship between spending on education and the percentage of female NEETs is obtained in quadrant (18), which is shown in Figure 18.

Other implications on economic integration are presented in quadrants (19) to (21). The relationship in quadrant (19), indicates that as the economic growth of country 2 increases, its percentage of female NEET decreases. Using the 45-degree line in quadrant (20), quadrant (21) shows the positive relationship between the growth rates of countries 1 and 2, that indicates the existence of synchronism in regional economic growth, which has implications in relation to the distribution of the benefits of integration.

The synchronysm in growth rates has implications in the fulfillment of the criteria for the adoption of a common currency in a monetary integration scheme, since the social spending of the member countries is conducive to the prevention or reduction of the percentages of female NEETs, which would give rise to the synchronism of economic growth rates, which would be obtained ex ante, thus validating monetary integration.

The negative relationship between the economic growth of country 2 and its percentage of female NEET is shows in quadrant (22); using this quadrant and quadrant (19), quadrant (23) shows the positive association between the percentage of female NEETS in countries 1 and 2. This indicates that the percentages of female NEETs increase or decrease in unison in the member countries, or all improve or all deteriorate, following the changes in spending on education.

It follows that the absence of categorical attention to the social problems of the member countries of the integration scheme would lead not only to weaken intra-regional trade, but also to the emergence of social problems with a regional scope.

\subsection{Percentage of Female NEET and Economic Vulnerability}

Figure 19 presents a model that shows that the increase of the percentage of female NEETs has an impact on increasing the economic vulnerability of a country.

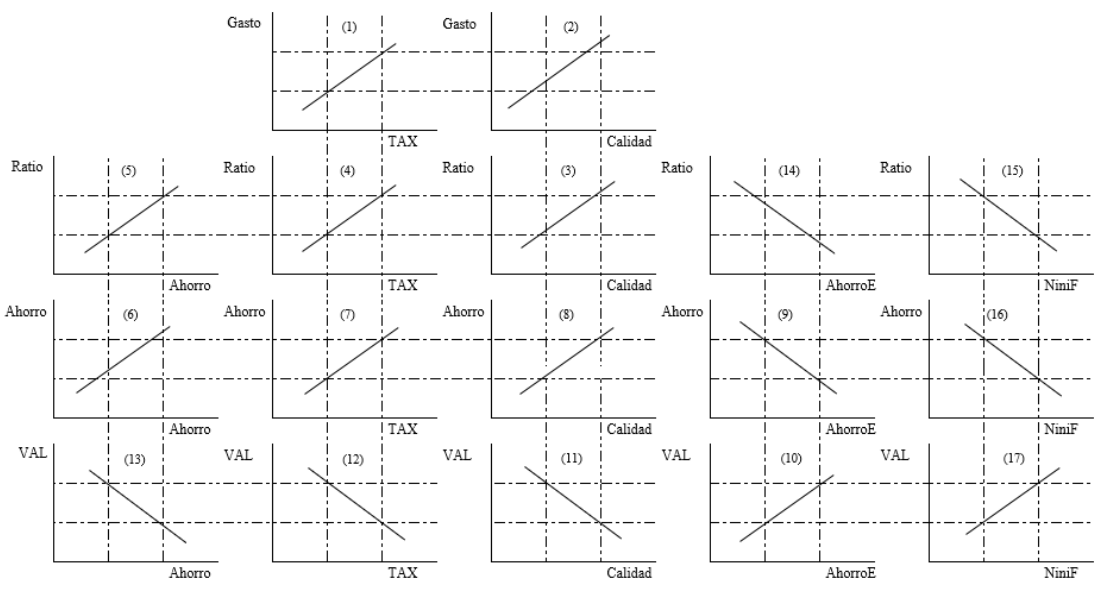

Figure 19. Female NEET and economic vulnerability 
Quadrant (1) shows the positive relationship between tax collection, Tax, and education spending, Gasto, while quadrant (2) shows that the increase in education spending leads to an increase in the quality of education, Calidad, as shown in Figure 20.

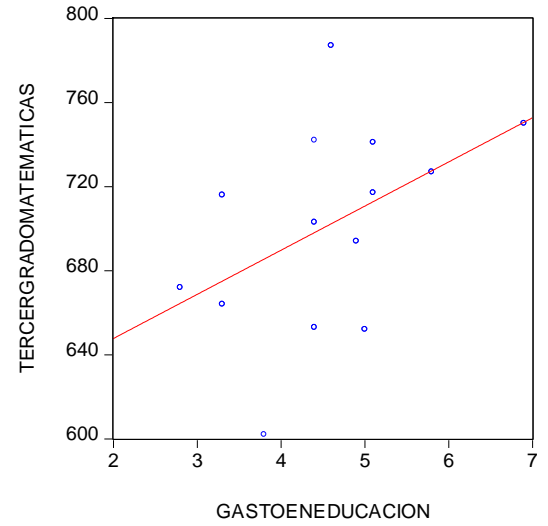

Figure 20. Expenditure on education and scores in third grade mathematics (tercergradomatematicas)

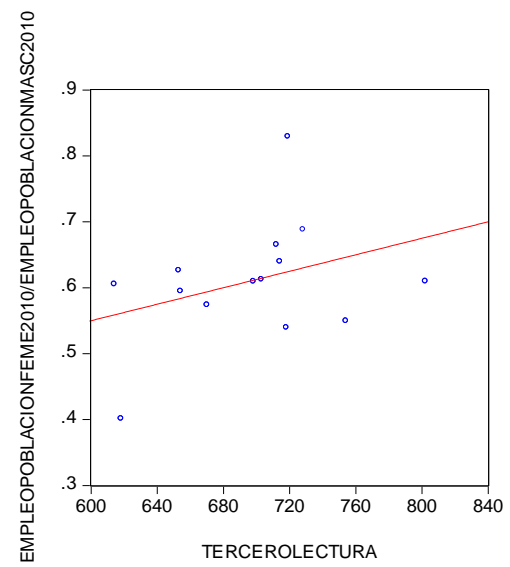

Figure 21. Quality of education and female to male employment ratio

Quadrant (3) shows the positive relationship between the quality of education and the ratio of female to male employment, Ratio, (Figure 21). In this way, a positive relationship between tax revenues, (tax1870), and said ratio is constructed in quadrant (4) (Figure 22).

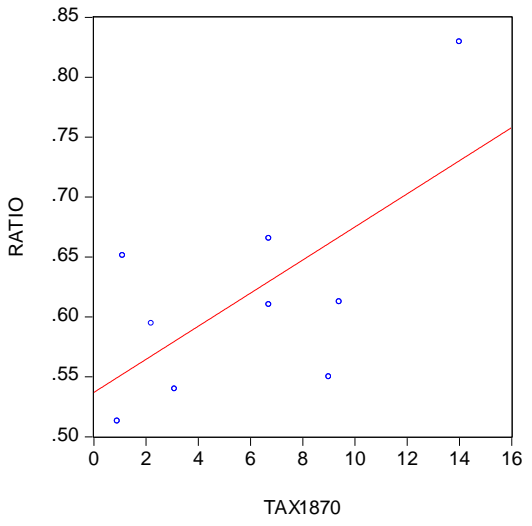

Figure 22. Taxes per capita in 1870 and ratio of female to male employment in 2010

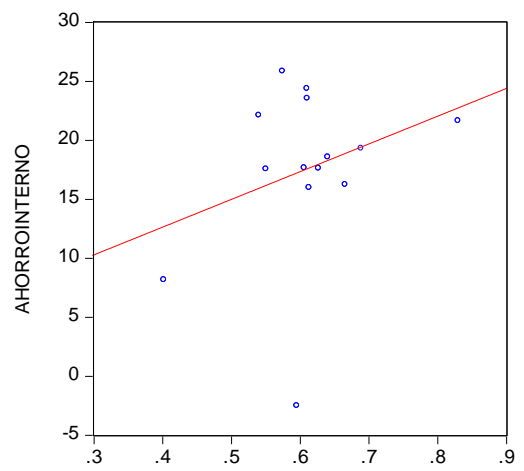

EMPLEOPOBLACIONFEME2010/EMPLEOPOBLACIONMASC2010

Figure 23. Ratio of female to male employment and domestic savings rate

Quadrant (5) shows the positive association between this ratio and the domestic saving rate, Ahorro, in accordance with the evidence presented by Seguino and Floro (2003) and by Caceres (2020), which showed that by increasing female employment relative to male employment, women acquire greater decision-making capacity at home in relation to the use of the family budget and, consequently, allocate more resources to saving and caring for children. This relationship is shown in Figure 23.

Using the 45-degree line in quadrant (6), one obtains with quadrants (7) and (8) the positive relationships between domestic savings, on the one hand, and tax revenues (Figure 24), and the quality of the education (Figure 25), on the other, while quadrant (9) shows the negative relationship between domestic and external savings, AhorroE. 


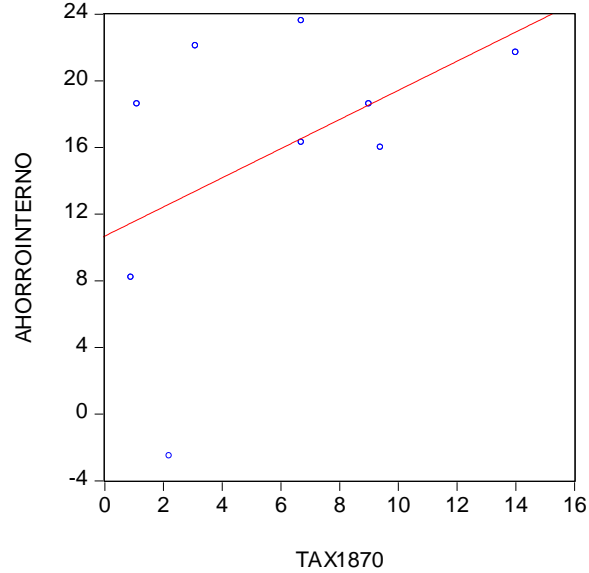

Figure 24. Tax revenues and domestic savings rate

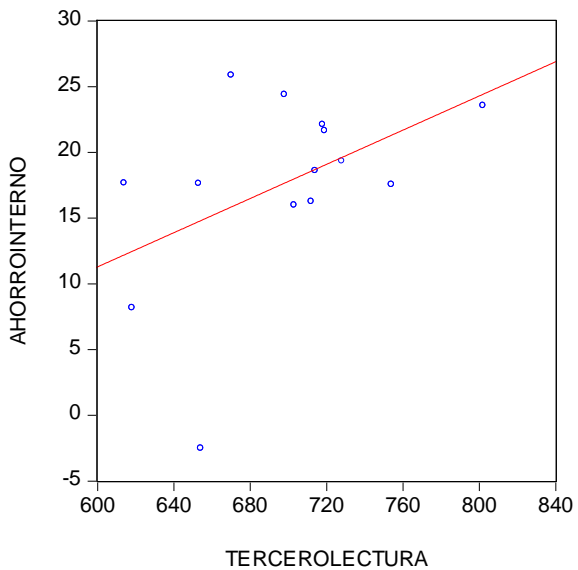

Figure 25. Quality of education and domestic savings rate

Given that external savings, or the negative of the deficit in the current account, is a determinant of external debt, and has been identified by Frankel and Saravelos (2012) as an early indicator of debt crisis, quadrant (10) presents the positive relationship between external savings, AhorroE, and economic vulnerability, VAL.

The inverse of per capita international reserves has been used as an indicator of economic vulnerability; Sachs, Tornell y Velasco 1996) have reported that the reduction of international reserves is an early warning signal of crisis; this also has been reported by Kaminsky and Elizondo (1996).

Quadrants (11), (12), y (13) show the negative relationships between economic vulnerability and education quality, tax revenues, and domestic savings. These relationships are shown in Figures 26, 27 and 28.
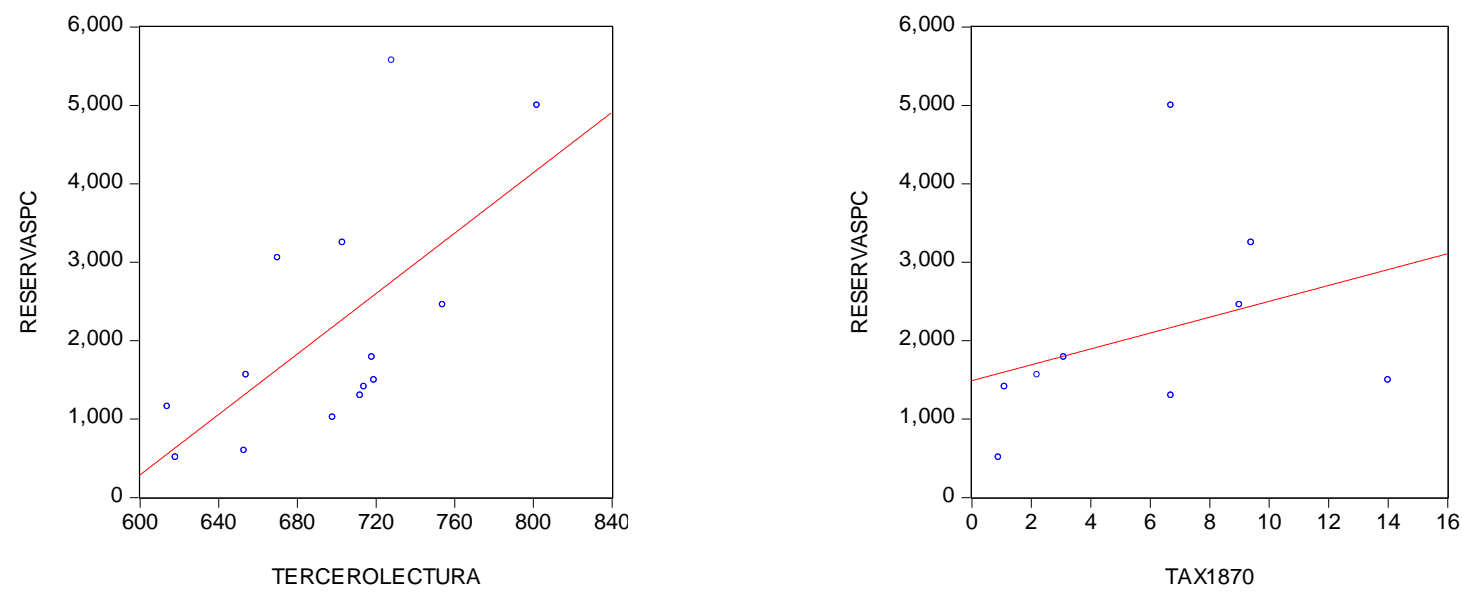

Figure 26. Quality of education and economic vulnerability Figure 27. Tax revenues and economic vulnerability

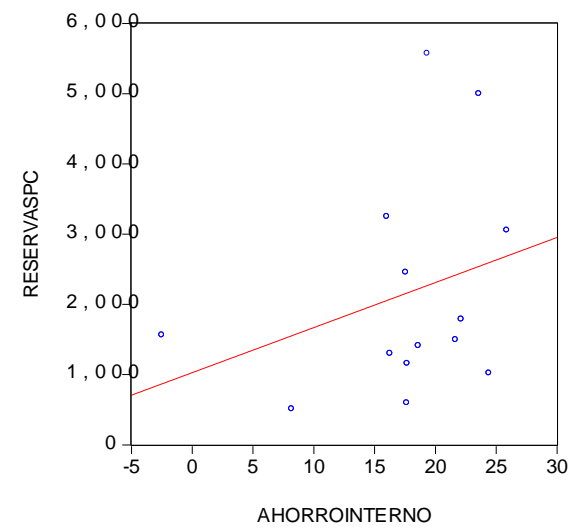

Figure 28. Domestic savings and economic vulnerability

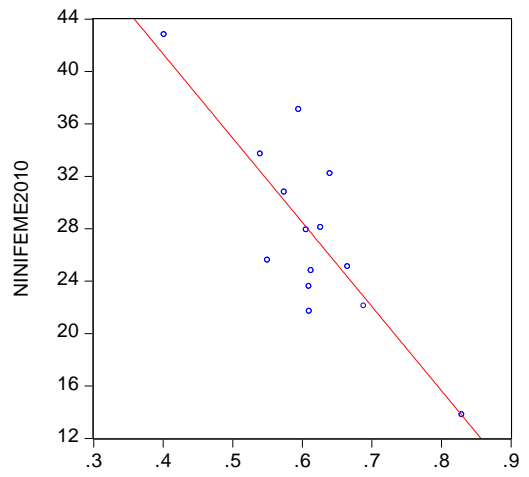

EMPLEOPOBLACIONFEME2010/EMPLEOPOBLACIONMASC2010

Figure 29. Ratio of female to male employment and percentage of female NEET. 
Quadrant (14) presents the negative relationship between the female to male employment ratio and the external savings rate, while quadrant (15) shows the negative relationship between the female to employment ratio and the percentage of female NEET, which is shown on Figure 29.

It can be seen in quadrant (16) that the reduction of the female NEET leads to the increase in domestic savings (Figure 30, and, therefore, quadrant (17) shows that the reduction in the percentage of female NEET reduces economic vulnerability, which is shown in Figure 31.

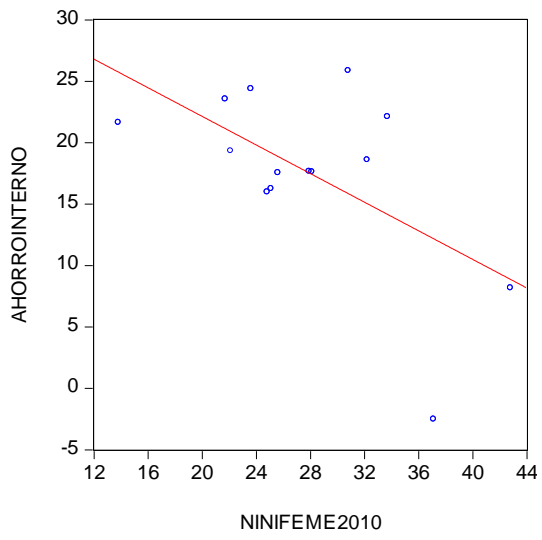

Figure 30. Percentage of female NEET and domestic savings rate

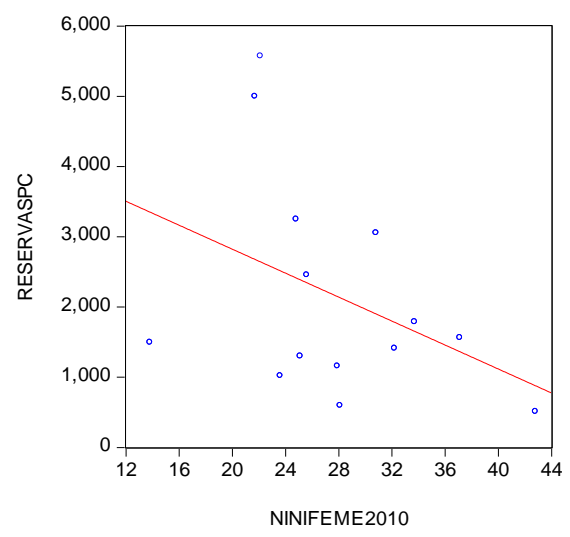

Figure 31. Percentage of female NEET and reserves per capita

Combating the prevalence of female NEETs constitutes a legitimate instrument of prudential macro policy. Efforts to reduce the incidence of female NEET represent the construction of a shield, or a safety net, that protects the macroeconomy of a country.

\subsection{Differences between Percentages of Female and Male NEETs}

Table 2 presents the results of the estimation of equations that express the difference between the percentages of female and male NEETs, in terms of adolescent fertility and other variables. Under the assumption that the variables impact in the same way the NEETs of both sexes, this difference could be interpreted as the percentage of female NEETs that is largely due to the discrimination and arbitrariness to which exclusively young women are subjected.

Equation (1) shows that the coefficient of adolescent fertility is significant and positive, and together with the qualitative variable QualiDR, which represents the case of the Dominican Republic, explains 73 percent of the variance of the difference between female and male NEETs. It could be inferred that adolescent fertility is an important cause of the high values of female NEET in some Latin American countries.

The adolescent fertility rate is closely related to the level of education in the respective country, and to the human opportunity indicator. The IOH is determined by social spending, (Caceres, 2018), so that the high percentages of female NEETs in Latin America can be associated with the low social spending that prevails in several countries.

In equation (2) it is observed that the poverty gap has a positive and significant coefficient at the 10 percent level, and the equation explains 80 percent of the variance. The implication is that poverty affects more decisively the percentage of female NEETs than the percentage of male NEETs.

Equation (3) indicates that the ratio of remittances to GDP has a positive and significant coefficient, which implies that remittances facilitate the entry of young women to the situation of NEET. For example, in Honduras, remittances, which reached 18 percent of GDP in 2010, contributed to an increase in the percentage of female NEETs relative to male NEETs by about 8 percentage points, for a given level of adolescent fertility.

In equation (4) it is observed that the coefficient of the percentage of the population that has completed secondary education, (Secondary), is negative and significant, which implies that secondary education attenuates the entry of young women to the situation of NEETs. Another implication is that increasing spending on education in a given country would contribute to reducing the percentage of female relative to male NEET and therefore to increasing the female labor force participation rate, and thus economic growth. 
Table 2. Difference between percentages of female and male NEETs (Dependent Variable: Female NEETs-MaleNEETs)

\begin{tabular}{lcccccc}
\hline \multicolumn{7}{c}{ Equation number: } \\
\hline Independent Variable & $(1)$ & $(2)$ & $(3)$ & $(4)$ & $(5)$ & $(6)$ \\
\hline Constant & -24.2476 & -16.6974 & -15.529 & -12.7004 & -8.5632 & -30.266 \\
& $(3.24)$ & $(2.07)$ & $(1.96)$ & $(1.11)$ & $(1.31)$ & $(3.25)$ \\
CualiDR & -25.4335 & -17.4468 & -20.8912 & -22.2807 & -30.8238 & -22.5171 \\
& $(4.18)$ & $(2.24)$ & $(3.58)$ & $(3.78)$ & $(6.75)$ & $(2.78)$ \\
AdolescentFertility & 0.6109 & 0.4438 & 0.4531 & 0.5525 & 0.3481 & 0.5814 \\
& $(5.94)$ & $(3.19)$ & $(3.57)$ & $(4.41)$ & $(3.39)$ & $(3.19)$ \\
Poverty & & 0.7041 & & & -22.2805 & $(2.48)$ \\
& & $(1.78)$ & & & -0.4222 & $(2.82)$ \\
Remittances & & & & & & \\
& & & & & & \\
SecondaryEducation & & & & & & \\
\end{tabular}

In equation (5) it is observed that the indicator of control of corruption has a negative and significant coefficient, implying that the fall in corruption in a given country would contribute to reducing the percentage of female NEETs in relation to the percentage of male NEETs. In this case, female NEETs would fall in absolute terms and, therefore, the fall in corruption would contribute to increasing female labor participation, female employment, and economic growth. This could be explained by the fact that, given the fall in corruption, young women perceive that they have a better chance of finding a job, and give up their situation of being at home. In addition, lower corruption corresponds to higher spending on education, which benefits young women. An extensive literature has exposed the negative role of corruption on labor participation (Cooray \& Dzhumashev, 2018).

The coefficient of the composite variable AdolescentFertility*Control Corruption is negative and significant, implying that the reduction in corruption attenuates the determining impact of adolescent fertility on the percentage of female NEET.

In equation (6) it is observed that the IDG has an insignificant coefficient, which implies that adolescent fertility captures all the discrimination and abuse that young woman are exposed to, and that leads them to enter the situation of NEETs in higher percentages compared with the percentage of male NEETs.

\section{Conclusions}

Some measures that may be valuable to solve the problem of female NEETs in the region are discussed.

-One is the establishment of national networks of day care centers with national coverage, which would allow young mothers to continue their studies or enter the labor market. The positive repercussions of low-cost day care centers on economic stability and family income have been described for several countries by various authors. This measure would also contribute to increasing female labor force participation, with positive impacts on economic growth and, by virtue of its role in increasing female employment, it would contribute to increasing domestic savings and economic stability. It should be noted that Rodgers (1994) found that the main determinant of the incidence of poverty in single mothers head of the household was their low level of education, and that the creation of networks of low-cost day care centers contributed substantially to their counting with time to study and increase their skills.

-A similar argument can be made in relation to conditional cash transfer programs that have led to positive results in several countries in the region, due to their role in combating school desertion. These programs have been effective in reducing domestic violence in Mexico (Angelucci, 2007), and, due to their role in reducing school desertion, have an impact on reducing crime (Ayers, 1998). Programs of this nature were decisive in the significant drop in poverty in Brazil, which allowed the middle class to increase by 30 million people. It has also been shown that children who have been beneficiaries of conditional voucher programs are more likely to graduate from high school than those who have not participated in these programs (Parker \& Vogl, 2018; Araujo et al., 2018 ).

-Providing scholarships for low-income youth can also be a means to combat school desertion. 
-The evaluations of early childhood education programs have shown their undeniable value in reducing school desertion and increasing the years spent in school by the beneficiaries. Furthermore, the evidence indicates that early or preschool education determines the good performance of beneficiary girls and boys in the labor market when they reach the adult age, and has been recognized by researchers as the most effective means of preventing violence (World Bank, 2011); furthermore, evaluations of these programs have shown that they are highly profitable, with benefits that easily outweigh costs (Black, Devereux, \& Salvanes, 2007).

-Preschool education gives rise to high returns by reducing crime. Belfield et al (2000) estimated the benefits of a preschool education program at $\$ 150,000$ per child participating in the program, due to the reduction in crime alone. Donahue and Siegelman (1998) have estimated that early childhood programs pay for themselves through the drop in crime.

-Importance resides in the investments conducive to increasing the quality of education, which would result in increasing the economic growth rate (Hanushek \& Woessmann, 2009; Caceres, 2018) and, as shown in this work, in reducing the percentage of female NEETs in a country.

\section{Conclusions}

In this work, variables that affect the percentage of female NEET have been identified, such as the underground economy, inequality of opportunities and low spending on education. These variables can actually be manifestations of a structure within the society and the economy of the countries, which acts to maintain a state of affairs from which the marginalization of certain groups of the population is a logical result.

Therefore, it is necessary to look for the underlying causes that determine the persistence of poverty and poor social performance in the region (with due exceptions). According to ECLA (2018), the man obstacles to development reside in a society grounded in privilege, which manifests itself in the control of the public apparatus by certain groups of economic power, with a view to providing them with benefits.

In other words, these are countries whose governments have been "captured", in the sense of Bardhan and Mookkherjee (2000). This control modality has been refined in some countries in a more advanced structure, so that it fits into what Acemoglu and Robinson (2008) call the "captured democracy", in which the state has all the public institutions of the three powers of the state, while citizens exercise their right to vote, but the whole apparatus is actually a "montage", designed by high-income groups to control the public sector for their own interests, under the validation of "democracy". Out of this "democracy" come the privatization of pensions, dollarization, part-time employment, deindustrialization, the reduction of income tax, the introduction of the value-added tax, NEETs, crowded prisons, caravans, and so on. Elections, and governments, come and go, but things remain unchanged. This is a situation that the most elegant development theories are not able to grasp.

Not addressing this problem represents opting for inequality, for "democracy" as a "business facilitator", for social exclusion, irregular emigration, and for violence.

This situation dates back centuries, originated in the abuses of colonial times, as described by Engerman and Sokoloff (2005), and has been reproduced through the centuries. But it should be noted that there is an important difference in relation to the past, with the entry into the scene of new and important actors into the national and international scenarios, who capitalize on social deterioration. Cárdenas, de Hoyos, and Szekely (2006),) reported that in Mexico the youth male and female populations face the dilemma of finding a job or joining the ranks of organized crime. This implies that the fiscal weakness of the state, in fact, may push the young population to the area of criminal activities, or to irregular emigration.

The role of economic openness as a determinant of youth who neither study or work is of special importance. Cárdenas, de Hoyos, and Szekely (2015) argue that the economic opening resulted in young people finding serious difficulties in finding employment in an environment in which small companies were being displaced by large companies and by imports

There are other economic reform measures that were undertaken in the 1980s and 1990s in the region, which have had perverse impacts on youth. The main result of the trade reform has been the high deficit in the trade account, as described by Santos (2002), Santos and Thirlwall (2004), and Stiglitz (2003, 2004), which should not be surprising. in view of the lack of historical and other rational support for trade liberalization. Likewise, trade reform is associated with the premature deindustrialization process that the region has experienced since the 1990s (Cáceres, 2018), which is also related to the fall in labor productivity since the 1980s (Cavalcanti et al., 2014; Caceres, 2018c). On the other hand, Kaminsky and Reinhardt (1999) have pointed out that financial reform is a trigger for banking crises. It should be noted that the evidence that the economic instability resulting from the reforms has adverse implications on school desertion in Mexico (Skoufias \& Parker, 2001), on youth 
violence in Brazil (World Bank, 2007), and in Colombia (Duque et al., 2003).

These "market economy" experiments, Stiglitz $(2003,2004)$ points out, never existed in the now developed countries, much less in the Asian "tigers", and have given rise to grave injuries to Latin American youth.

It is valid to argue that in the economy based on privilege, the economic power groups have not been net winners, given the high costs implied by violence, which undoubtedly reduces profits; likewise, the tendencies towards crisis and slow economic growth would tend to punish earnings. In other words, greed generates "opportunity costs." One of the manifestations of abuse in the region is the high rate of tax evasion, which for the region as a whole, ECLAC (2019) has estimated it at 6.3 percent of regional GDP in 2017. This limited tax collection does not enable governments to address the areas that matter for development, education, health and social protection.

It should be noted that low taxation, or specifically, tax evasion, has implications for people's human rights. There is evidence that in countries with high percentages of female NEETs, life expectancy tends to be low, which represents a violation of the right to life stipulated in article 3 of the Universal Declaration of Human Rights. Likewise, poverty, which also results from low social spending, represents a challenge to the right to life, given the evidence presented by Duflo and Banerjee (2007) that poor people tend to die at an earlier age than non-poor people; these authors concluded: "poverty does kill". It has also been pointed out that people who have experiences of unemployment die earlier than people who did not go through this situation (Junakar, 1991). It should be noted that the experience of NEETs has effects that are felt throughout people's lives: high percentages of NEETs at the age of 15 to 20 are associated with lower wages of the same cohorts later in life when they reach 35 and 40 years; This adverse effect is also detected in the case of employment prospects (Szekely \& Karver, 2015).

These human rights violations constitute valid arguments that poor people and NEETs can use to sustain their cases in international courts and to request protection measures so that their lives are not cut short, or reduced, due to their situation of poverty, or being NEET, with a view to motivating the courts to issue resolutions compelling the respective states to increase social spending. In the way of litigation in the international courts is that marginalized segments of the Latin American population can receive responses to assert their rights to life, work, education, and to eradicate the "culture" of abuse. and privilege. Otherwise, abuse, poverty, NEETs violence, premature death, ad irregular emigration will continue.

The devastating experiences of broad segments of the region's youth may well be classified as vivid results from what Krugman (2020) has called The Economy of Cruelty. It is now imperative to do justice to young people, who undoubtedly deserve better lives.

Justice and only justice you shall do (Deuteronomy 16, 20).

\section{References}

Acemoglu, D., \& James, R. (2008). Persistence of Power, Elites, and Institutions. American Economic Review, 98. Nashville, Tennessee, American Economic Association. https://doi.org/10.1257/aer.98.1.267

Angelucci, M. (2007). Love on the Rocks: Alcohol Abuse and Domestic Violence in Rural Mexico. IZA Discussion Paper no. 2706. https://doi.org/10.2139/ssrn.981690

Araujo, M. C. et. al. (2018). Se mejora la Escolaridad con Becas de Mayor Monto? La Evidencia de las Localidades Urbanas de Mexico. Working paper 8777, Washington DC, InterAmerican Development Bank.

Ayres, R. L. (1998). Crime and Violence as Development Issues in Latin America and the Caribbean. Washington DC, World Bank. https://doi.org/10.1596/0-8213-4163-4

Banerjee, A. V., \& Ester, D. (2007). Aging and Death Under A Dollar A Day. Working paper 13683, Cambridge, Massachussets, National Bureau of Economic Research. https://doi.org/10.3386/w13683

Bardhan, P., \& Dilip, M. (2000). Capture and Governance at Local and National Levels. American Economic Review, Papers and Proceedings, 90. https://doi.org/10.1257/aer.90.2.135

Belfield, C. R., Nores, M., Barnett, S., \& Schweinhaart, L. (2006). The High/Scope Perry Pre School Program: Cost-Benefit Analysis Using Data from the Age-40 Follow up. Journal of Human Resources, 41. https://doi.org/10.3368/jhr.XLI.1.162

Buehn, A., \& Friedrich, S. (2012). Shadow Economies Around the World: Novel Insights, Accepted Knowledge, the New Estimates. International Tax and Public Finance, 19, 139-171. https://doi.org/10.1007/s10797-011-9187-7

Caceres, L. R. (2017). Stylized Facts about Happiness and Violence in Central America. Journal of Business Diversity, 17, 38-78. 
Caceres, L. R. (2018a). Des-industrialización, Trabajo y Violencia en El Salvador. Revista de la Cepal. https://doi.org/10.18356/09a279fd-es

Caceres, L. R. (2018b). Calidad de la Educación en América Latina. Unpublished.

Caceres, L. R. (2018c). Productividad Laboral en America Latina. Estudios Centroamericanos, 73(754). https://doi.org/10.51378/eca.v73i754.3169

Caceres, L. R. (2019). Trust in Government in Latin America. Revista Mexicana de Economia y Finanzas.

Cárdenas, M., Rafael, de H., \& Miguel, S. (2016). Idle Youth in Latin America: A Persistent Problem in a Decade of Prosperity. Economia, 5, 1-40.

Cavalcanti, F. P., Samuel, De A. P., \& Fernando, A. V. (2014). On the Evolution of Total Factor Productivity in Latin America. Economic Inquiry, 51.

CEPAL. (2018). La Ineficiencia de la Desigualdad. Santiago de Chile.

CEPAL. (2019). Fiscal Panoram of Latin America and the Caribbean. Santiago de Chile.

Cerrutti, M. (2000). Economic Reform, Structural Adjustment and Female Labor Force Participation in Buenos Aires. Argentina World Development, 28. https://doi.org/10.1016/S0305-750X(99)00163-1

Cooray, A., \& Ratbek, D. (2018). The Effect of Corruption on Labor Market Outcomes. Economic Modelling, 30. https://doi.org/10.1016/j.econmod.2018.05.015

Cortes, G. M., Nir, J., \& Henry, E. S. (2018). The "End" of "Men" and the Rise of Women in the High-Skilled Labor Market. Working paper 24274, Cambridgfe, Massachussetts, NBER. https://doi.org/10.3386/w24274

Cunningham, W., \& Emilie, B. (2010). Factors That Predispose Youth to Risk in Mexico and Chile. Working paper 5333, Washington DC, World Bank. https://doi.org/10.1596/1813-9450-5333

de Hoyos, R., Carlos, G. F., \& J. Vicente, V. M. (2016). Idle Youth in Mexico. Trapped Between the War on Drugs and Economic Crisis. Working paper 7558, Washington DC, World Bank. https://doi.org/10.1596/1813-9450-7558

de Hoyos, R., Halsey, R., \& Anna, P. (2015). Out of School and Out of Work: A Diagnostic of Ninis in Latin America. Working paper 7548, Washington DC, World Bank. https://doi.org/10.1596/1813-9450-7548

Donahue, J., \& Siegelman, P. (1998). Allocating Resources Among Prisons and Social Programs in the Battle Against Crime. The Journal of Legal Studies, 27. https://doi.org/10.1086/468012

Duque, L. F., klevens, J., \& Ramirez, C. (2003). Cross-Sectional Survey of Perpetrators, Voctims, and Witnesses of Violence in Bogota, Colombia. Journal of Epidemiology and Community Health, 57. https://doi.org/10.1136/jech.57.5.355

Easterlin, R. (1981). Why Isn't the Whole World Developed? The Journal of Economic History, 41. https://doi.org/10.1017/S0022050700042674

Engerman, S. L., \& Kenneth, L. S. (2005). Colonialism, Inequality, and Long-Run Paths of Development. Working paper 11057, Cambridge, Massachussetts, NBER. https://doi.org/10.3386/w11057

Frankel, J., \& George, S. (2012). Can Leading Indicators Asses Country Vulnerability. Journal of International Economics, 87. https://doi.org/10.1016/j.jinteco.2011.12.009

Hanushek, E. A., \& Ludger, W. (2009). Schooling, Cognitive Skills and the Latin American Growth Puzzle. Working paper 15066, Cambridge Massachusetts, NBER. https://doi.org/10.3386/w15066

Junakar, P. N. (1991). Unemployment and Mortality in England and Wales: A Preliminary Analysis. Oxford Economic Papers, 43. https://doi.org/10.1093/oxfordjournals.oep.a042001

Kaminsky, G., \& Carmen, R. (1999).The Twin Crisis: The Causes of Banking and Balance of Payments Problems. American Economic Review, 89. https://doi.org/10.1257/aer.89.3.473

Lloyd, C., \& Clark, W. (2000). The Effects of Primary School Quality on School Drop Out Among Kenyan Girls and Boys. Comparative Education Review, 44. https://doi.org/10.1086/447600

Molinas, V., Jose, R., Ricardo, P. de B., Jaime, S., ... \& Amer, H. (2011). Do Our Children Have a Chance? World Bank. https://doi.org/10.1596/978-0-8213-8699-6

Ostry, J. D., Jorge, A., Raphael, E., \& Chris, P. (2018). Economic Gains from Gender Inclusion: New Mechanisms, New Evidence. Staff Discussion Note 18/06, Washington DC, International Monetary Fund. 
https://doi.org/10.5089/9781484337127.006

Parker, S. W., \& Vogl, T. (2018). Do Conditional cash Transfers Improve Economic Outcomes in the Next generation? Evidence from Mexico. NBER working papers 24303. https://doi.org/10.3386/w24303

Parker, S., \& Emmanuel, S. (2004). The Added Worker Effect Over the Business Cycle: Evidence from Urban Mexico. Applied Economics Letters, 11. https://doi.org/10.1080/1350485042000235693

Paz, J. (2009). El Efecto del Trabajador Adicional: Evidencia para Argentina (2003-2007). Cuadernos de Economía, 46. https://doi.org/10.4067/S0717-68212009000200005

Phillips, P. C. B., \& Bruce, E. H. (1990). Statistical Inference in Instrumental Variables Regressions with I(1) Processes. Review of Economic Studies, 57. https://doi.org/10.2307/2297545

Rodgers, J. R. (1994). Female-Headed Families: Why are They So Poor? Review of Social Economy. https://doi.org/10.1080/758519572

Rodrik, D. (2006). Goodby Washington Consensus, Hello Washington Confusion? Journal of Economic Literature, 44. https://doi.org/10.1257/jel.44.4.973

Sachs, J., Aaron, T., \& Andres, V. (1996). Financial Crisis in Emerging Markets: The Lessons from the 1995. Brookings Papers on Economic Activity, 26. https://doi.org/10.2307/2534648

Santos, P. A. (2002). The Effects of Trade Liberalization in Imports in Selected Countries. World Development, 30. https://doi.org/10.1016/S0305-750X(02)00014-1

Santos, P. A., \& Anthony, P. T. (2004). The Impact of Trade Liberalization on Export Growth, the Balance of Trade and the Balance of Payments in Developing Countries. The Economic Journal, 114. https://doi.org/10.1111/j.0013-0133.2004.00187.x

Seguino, S., \& Floro, M. S. (2003). Does Gender have any Effect on Aggregate Saving? International Review of Applied Economics, 17. https://doi.org/10.1080/0269217032000064026

Skoufias, E., \& Susan, P. (2006). Job Loss and Family Adjustments in Work and Schooling During the Mexican Peso Crisis. Journal of Population Economics, 19. https://doi.org/10.1007/s00148-005-0005-3

Sokoloff, K., \& Eric, Z. (2007). Inequality and the Evolution of Institutions of Taxation, in Sebastian Edwards et al. The Decline of Latin American Economies. Chicago, University of Chicago Press. https://doi.org/10.7208/chicago/9780226185033.003.0004

Stiglitz, J. (2003). El Rumbo de las Reformas: Hacia una Nueva Agenda para America Latina. Revista de la Cepal, 80. https://doi.org/10.18356/46a2a558-fr

Stiglitz, J. (2004). Globalization and Growth in Emerging Markets and the New Economy. Journal of Policy Modeling, 25. https://doi.org/10.1016/j.jpolmod.2004.04.010

Szekely, M., \& Jonathan, K. (2015). Youth Out of School and Out of Work in Latin America. A Cohort Approach. Working paper 7421, World Bank, Washington DC. https://doi.org/10.1596/1813-9450-7421

TERCE. (2016). Tercer Estudio Regional Comparativo y Explicativo 2016. Unesco, Santiago de Chile.

World Bank. (2007). Youth at Risk in Brazil. Report no. 32310-BT, Washington DC.

World Bank. (2011). World Development Report 2011. Crime, Security and Development, Washington DC.

\section{Note}

Note 1. The IOH was developed by the World Bank, (Molinas et al., 2011).

\section{Copyrights}

Copyright for this article is retained by the author(s), with first publication rights granted to the journal.

This is an open-access article distributed under the terms and conditions of the Creative Commons Attribution license (http://creativecommons.org/licenses/by/4.0/). 